\title{
Transposition of great arteries: new insights into the pathogenesis
}

\section{Marta Unolt ${ }^{1}$, Carolina Putotto ${ }^{1}$, Lucia M. Silvestri ${ }^{1}$, Dario Marino ${ }^{1}$, Alessia Scarabotti ${ }^{1}$, Valerio Massaccesi ${ }^{1}$, Angela Caiaro ${ }^{1}$, Paolo Versacci ${ }^{1}$ and Bruno Marino ${ }^{1,2}$ *}

'Department of Pediatrics, "Sapienza" University of Rome, Rome, Italy

2 Eleonora Lorillard Spencer Cenci Foundation, Rome, Italy

\section{Edited by:}

Cecile Tissot, The University

Children's Hospital, Switzerland

\section{Reviewed by:}

Giuseppe Limongelli, Second

University of Naples, Italy

Yves Durandy, Institut

Cardiovasculaire Paris Sud, France

Patrick O. Myers, Geneva University

Hospitals, Switzerland

\section{*Correspondence:}

Bruno Marino, Department of

Pediatrics, "Sapienza" University of

Rome, Viale Regina Elena 324, 00161

Rome, Italy

e-mail: bruno.marino@uniroma1.it
Transposition of great arteries (TGA) is one of the most common and severe congenital heart diseases (CHD). It is also one of the most mysterious $\mathrm{CHD}$ because it has no precedent in phylogenetic and ontogenetic development, it does not represent an alternative physiological model of blood circulation and its etiology and morphogenesis are still largely unknown. However, recent epidemiologic, experimental, and genetic data suggest new insights into the pathogenesis. TGA is very rarely associated with the most frequent genetic syndromes, such asTurner, Noonan, Williams or Marfan syndromes, and in Down syndrome, it is virtually absent. The only genetic syndrome with a strong relation with TGA is Heterotaxy. In lateralization defects TGA is frequently associated with asplenia syndrome. Moreover, TGA is rather frequent in cases of isolated dextrocardia with situs solitus, showing link with defect of visceral situs. Nowadays, the most reliable method to induce TGA consists in treating pregnant mice with retinoic acid or with retinoic acid inhibitors. Following such treatment not only cases of TGA with d-ventricular loop have been registered, but also some cases of congenitally corrected transposition of great arteries (CCTGA). In another experiment, the embryos of mice treated with retinoic acid in day 6.5 presented Heterotaxy, suggesting a relationship among these morphologically different $\mathrm{CHD}$. In humans, some families, beside TGA cases, present first-degree relatives with CCTGA. This data suggest that monogenic inheritance with a variable phenotypic expression could explain the familial aggregation of TGA and CCTGA. In some of these families we previously found multiple mutations in laterality genes including Nodal and ZIC3, confirming a pathogenetic relation between TGA and Heterotaxy. These overall data suggest to include TGA in the pathogenetic group of laterality defects instead of conotruncal abnormalities due to ectomesenchymal tissue migration.

Keywords: transposition of great arteries, heterotaxy, genetics of congenital heart diseases, embryology of congenital heart diseases, experimental animal models

\section{INTRODUCTION}

Transposition of the great arteries (TGA) is one of the most common and severe, but also one of the most mysterious, congenital heart diseases (CHD).

With a prevalence of 3,54/10,000 live births in Europe, it is the fourth most common type of major cardiac defect (1), representing $5 \%$ of all $\mathrm{CHD}$ and $34 \%$ of conotruncal defects with situs solitus (2).

It is a severe CHD: indeed, if not treated, it is the leading cause of cardiac death in neonates and infants (3).

Last but not least, it is still a rather mysterious CHD: in phylogenetic and ontogenetic development it has no precedent (4); it does not represent an alternative physiological model of blood circulation (5); its etiology and its morphogenesis are still largely unknown (2).

Over the last years, great improvements have been made in diagnosis, as well as in medical and surgical treatment of this CHD (5-10). As a consequence, nowadays, the overall survival of these patients is significantly better (11). In this review we report on the recent genetic and embryological researches on this fascinating CHD.

\section{PATHOGENETIC CLASSIFICATION}

In 1986 Clark (12) introduced a pathogenetic classification of CHDs, that has been commonly accepted (13). This classification consists of six causative mechanism of CHDs: (i) ectomesenchymal tissue migration abnormalities; (ii) intracardiac blood flow defects; (iii) cell death abnormalities; (iv) extra cellular matrix abnormalities; (v) abnormal targeted growth; (vi) anomalies of visceroatrial situs and ventricular looping. TGA, classically considered as a conotruncal defect, according to Clark's classification was considered an anomaly of ectomesenchymal tissue migration.

On the other hand, in the Baltimore-Washington Infant Study, a fundamental epidemiologic investigation of $\mathrm{CHD}$, Ferencz et al. showed that extracardiac anomalies had different prevalence in TGA ( $10 \%$, mostly kidney and cerebral anomalies) in comparison with other conotruncal defects (35\%), such as tetralogy of Fallot, truncus arteriosus, and interrupted aortic arch, which 
are frequently associated with DiGeorge syndrome and del22q11 $(2,14)$. Moreover, in this study TGA resulted more common in males than females. So the Authors suggested to consider TGA as a CHD etiologically different than others conotruncal defect (2).

\section{EMBRYOLOGIC THEORIES}

There are two main theories which try to explain the embryological mechanisms of TGA.

One theory, formulated by Goor and Edwards $(15,16)$, suggests that TGA is caused by the lack of the normal, clockwise (when the heart is viewed from above), rotation of the aorta toward the left ventricle. This defect of infundibular rotation is supposed to be caused by an abnormal resorption or underdevelopment of the subpulmonary conus with an abnormal persistence of the subaortic conus. Therefore, according to this theory, TGA is an extreme case in the spectrum of "dextroposition of the aorta" that goes from various forms of double outlet right ventricle, through tetralogy of Fallot, up to malalignment type of ventricular septal defects (17).

The second theory, proposed by de la Cruz $(18,19)$, focuses on abnormal spiraling of the aorto-pulmonary septum. She suggested that in the embryogenesis, either normal or pathological, there is no rotation at the infundibular level. TGA is due, instead, to a linear rather than spiral development of aorto-pulmonary septum, that puts the forth aortic arch (the future aorta) in contact with the anterior conus, situated on the right ventricle.

There are arguments both in favor and against each of these theories.

The "infundibular theory" seems to explain better cases of TGA with ventricular septal defect and with a certain degree of pulmonary overriding, which are morphologically similar to the double outlet right ventricle. It is less helpful, though, in explaining cases with intact ventricular septum.

On the other hand, the "extracardiac theory" does not account for the great variability of infundibular morphology in this cardiac defect $(20,21)$.

However, a recent study showed that a spiraling migration (clockwise when viewed from above) of cells from the right and left secondary heart field is necessary for the elongation and a proper alignment of the pulmonary outflow tract, so that it may acquire its right-handed spiral pattern $(22,23)$. In 2006, Bajolle et al. (24) demonstrated the occurrence in Pitx2 mutant embryos of conotruncal defects with rotational anomalies, including TGA (Figure 1), which confirms the importance of the spiral movement of outflow tract $(18,19)$.

\section{GENETIC SYNDROMES AND EXTRACARDIAC MALFORMATIONS}

Transposition of great arteries is very rarely associated with the most frequent genetic syndromes, such as Turner, Noonan, Williams or Marfan syndromes (Table 1), and in Down syndrome, it is virtually absent (25). It is interesting to note that TGA might be sporadically associated with trisomy 8 and 18, with VACTERL and CHARGE syndromes $(2,14)$, as well as with tuberous sclerosis (26), deletion of the long arm of chromosome 11 (27) and of the short arm of chromosome 18 (28) (Table 1). Moreover, in our patients with TGA, we have observed also isolated cases of anomalies of chromosome 3, 15, X (unpublished data) (Table 1).

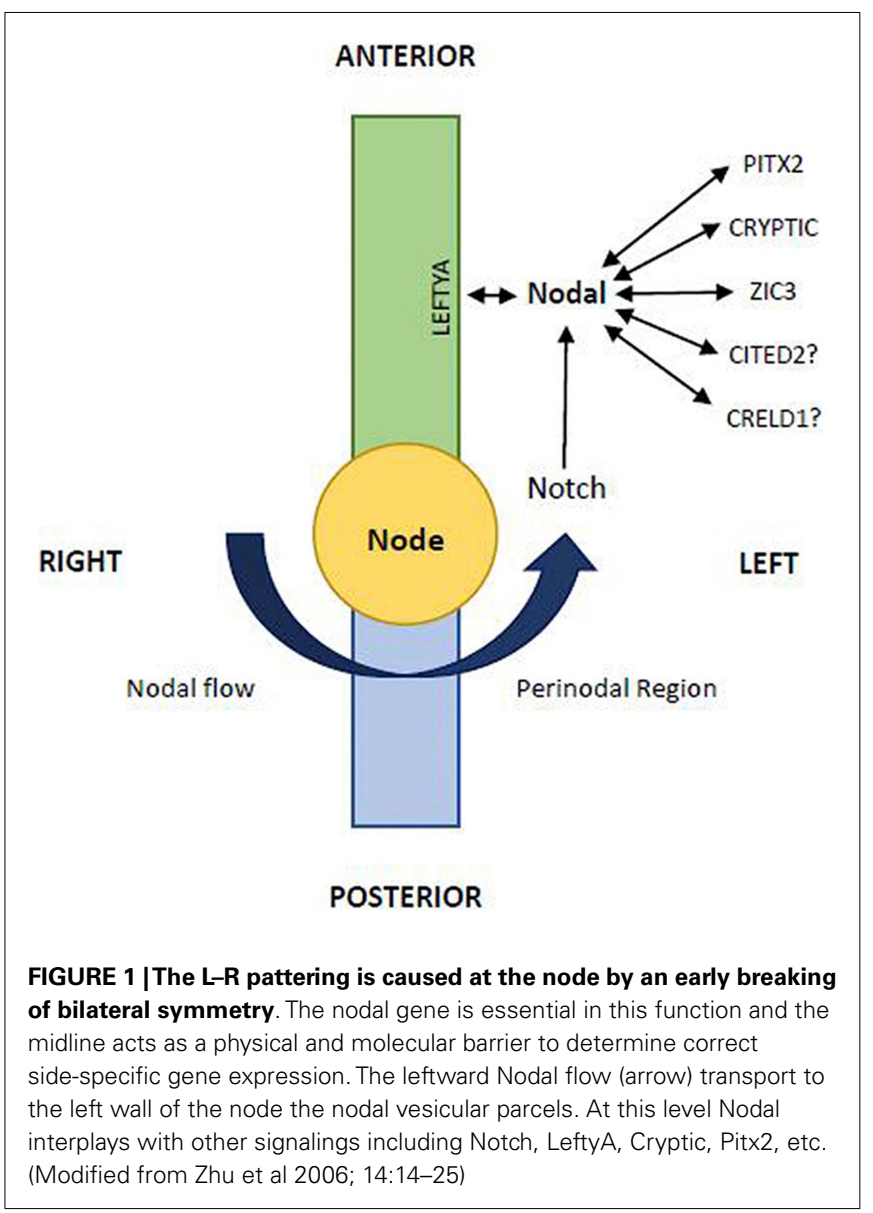

Furthermore, extracardiac anomalies are extremely rare in TGA patients, and include mostly kidney diseases and cerebral abnormalities (2).

The association of TGA with DiGeorge/Velocardiofacial Syndrome and with del22q11 is a topic that deserves wider discussion. Patient with DiGeorge syndrome may present TGA $(14,29)$, as well as patient with del22q11 (30-33) (Table 1). Animal experiments have demonstrated that the ablation of neural crest in chick embryos may results in TGA (34). Nevertheless TGA cannot be considered a characteristic cardiac defect of del22q11 syndrome, unlike such defects as tetralogy of Fallot, truncus arteriosus, and interrupted aortic arch type B (33). Instead only $1 \%$ of patient with TGA have del22q11. Thus it is possible to hypothesize a pathogenetic relationship between TGA and del22 but their association should be considered rare and sporadic (30-33).

The only genetic syndrome with a strong relation with TGA is the Heterotaxy (Table 1). First of all, TGA is rather frequent in cases of isolated dextrocardia with situs solitus, showing link with defect of visceral situs (35). Moreover, in lateralization defects (Heterotaxy or isomerisms) TGA is frequently associated with complete atrioventricular canal (CAVC), mostly in asplenia syndrome (right isomerism). TGA associated with CAVC has been reported in almost $100 \%$ of cases of asplenia syndrome $(35,36)$, with d-ventricular loop $\{A, D, D\}$ as well as with l-ventricular loop $\{A, L, L\}$. On the other hand, it is interesting to note that TGA is 
Table 1 | Genetic and non-genetic causes of TGA.

\begin{tabular}{ll}
\hline Genetic $\quad$ Syndromic & Heterotaxy (right isomerism) (35) \\
& Trisomy $8(2,14)$ \\
& Trisomy $18(2,14)$ \\
& VACTERL $(2,14)$ \\
& CHARGE $(2,14)$ \\
& Tuberous sclerosis (26) \\
& Deletion 11q (27) \\
& Deletion 18p (28) \\
& Anomalies chromosome 3, 15, X \\
& (unpublished data) \\
& DiGeorge/deletion 22q11 (14, 29-33) \\
& Turner syndrome (25) \\
& Noonan syndrome (25) \\
& Williams syndrome (25) \\
& Marfan syndrome (25) \\
& ZIC3 (41-43, 45) \\
& Nodal (44, 47) \\
& CFC1 (45, 46) \\
& Smad2 (44) \\
& Maternal diabetes (56, 57) \\
Non-syndromic & Maternal infections (14) \\
Ionizing radiations (14) & Pesticides (52) \\
& Ibuprofen (14) \\
& Antiepileptic drugs (53) \\
& Hormonal drugs (54) \\
& Other drugs (55) \\
& In vitro fertilization (58) \\
\hline Teratogens &
\end{tabular}

significantly rarer in polysplenia syndrome (left isomerism): in these cases great arteries are usually normally related $\{A, D, S\}$ or "inversely" normally related $\{A, L, I\}(35,37)$. This different prevalence has statistical significance (35-37), and has to be given a pathogenetic explanation.

Also in experimental animal models of Heterotaxy syndrome, TGA has been frequently reported, both in d-ventricular loop and in l-ventricular loop (38-40). It is worth noting that in some large families with recurrence of Heterotaxy and ZIC3 gene mutation (41-43) (Table 1), besides cases with situs inversus, with polysplenia or asplenia, there are cases of congenitally corrected transposition of great arteries (CCTGA) with situs solitus $\{S, L, L\}$. Therefore, we can suppose, therefore, that the same genetic mechanism could produce variable phenotypes in these families, including not only different kinds of Heterotaxy (asplenia or polysplenia), but also situs solitus CCTGA. Moreover, in mice knockout of Smad 2 and Nodal gene (genes involved in the process of laterality determination) leads to TGA associated with right pulmonary isomerism of the lung, in more than $50 \%$ of cases (44) (Table 1). Finally, in some patients with isolated or syndromic TGA have been observed mutations of ZIC3 (45), CFC1 (45, 46), and Nodal (47) (Table 1). All these are "laterality genes" associated with Heterotaxy (Figure 1).

A possible relationship between TGA and anomalies of ventricular looping has been already speculated in times past $(1,48-50)$, but scientific literature has not supported this hypothesis (51). Nowadays, the recent evidences suggest that TGA is most closely associated with the Heterotaxy syndrome.

\section{TERATOGENS AND EXPERIMENTAL ANIMAL MODELS}

An important issue, in the etiological and epidemiological studies of the TGA, is the occurrence of this CHD due to intake of teratogens, especially pesticides, by mothers (52) (Table 1). Cases of TGA associated with intake of antiepileptic (53), hormonal (54), and other drugs (55) are rarely reported, while the prevalence of TGA is higher in infants of diabetic mothers $(56,57)$ and as result of maternal infection (such as flu), intake of ibuprofen or ionizing radiation (14), as well as in cases of in vitro fertilization (58) (Table 1). A reduced occurrence of CHD, including TGA, has been reported as result of periconceptional intake of folic acid, which may be considered a protective factor against congenital malformations (59).

To induce TGA with teratogens in experimental animal models is quite difficult. Initially radiations and trypan blue were used, but now the most reliable method consist in treating pregnant mice with retinoic acid $(1,38)$. It is interesting to note that following such treatment not only cases of TGA with d-ventricular loop have been registered, but also some cases of TGA with 1ventricular loop (CCTGA). In another experiment, the embryos of mice treated with retinoic acid in days 6.5 presented Heterotaxy. We could explain the differences in the cardiac phenotype thus obtained with a different timing of teratogen treatment $(1,38)$. This notwithstanding, the pathogenetic mechanism seems to be the same, suggesting that there is a relationship among these morphologically different cardiac defects.

We recently obtained TGA by administration of a retinoic acid competitive antagonist in pregnant mice (60), showing that critical levels of retinoic acid must be present for normal heart and conotruncal development. These teratogenic effects may be consistently reduced by folic acid and methionine supplementation (61). Based on these data and following the results of further experiments, we suggested that the teratogenic development of TGA was due to Hifl $\alpha$ down-regulation in response to blocking retinoic acid (62). Hif1 $\alpha$ has an essential role in cardiac embryology and one of his downstream target Cited 2 is involved in left/right determination (Figure 1). Overall these results confirm a pathogenetic links between TGA and lateralization defects with Heterotaxy.

\section{FAMILIAL RECURRENCE}

Usually TGA is considered to have a low risk of familial recurrence. The English multicentric study by Burn et al. reported no familial cases of TGA (63). Our experience on this topic is rather different (64-66): in a multicentric Italian study the recurrence rate in siblings of patients with TGA were calculated at $1.7 \%$ (66). It is interesting to underline that in some families, beside TGA $\{S, D, D\}$ cases, there were first-degree relatives (siblings or parents) with CCTGA $\{\mathrm{S}, \mathrm{L}, \mathrm{L}\}$. This data suggest that monogenic inheritance (autosomal dominant or recessive) with a variable phenotypic expression could explain the familial aggregation of TGA and CCTGA. In some of these families we found multiple mutations in laterality genes including Nodal and ZIC3 (Figure 1), confirming a pathogenetic relation between TGA and Heterotaxy (67). 


\section{VENTRICULAR LOOPING AND SPIRALITY, HETEROTAXY, AND TRANSPOSITION}

Ventricular looping is genetically determined in all vertebrates including humans, and it represents the first morphological sign of L-R asymmetry in embryonic development (68).

In normal embryogenesis the rightward looping of the heart causes d-ventricular loop, continues with a looping movement that brings the right ventricle anteriorly, and finally involves the infundibula and the great arteries in a "rightward spiralization." As a result of this movement the ventricles, infundibula, and great arteries fall into their regular position. The "rightward spiralization" of the heart represents a pattern corresponding also with the normal rightward rotation of the bowel (69) and the normal cerebral asymmetry $(70,71)$.

It is remarkable that the same rightward spiralization is prevalent, though not exclusive, in the development of other organisms such as shells (72) (Figure 2), some bacteria including Bacillus subtilis (73) and some climber plant including Convolvulus arvensis (74).

We have previously suggested that the normal (right-handed) spiral pattern of the great arteries and the prevailing right-handed spiral pattern of snail shells show some phenotypic similarities (35, 75-77) (Figure 2).

Our morphological observations of cardiac defects in laterality disorders, including TGA, showed that in persons with situs inversus, the normal (right-handed) spiral pattern of the great arteries is inverted, showing a left-handed spiral pattern similar to a minority of shells. On the other hand, in subjects with TGA with or without asplenia/right isomerism any spiral pattern of the great arteries is lost: the two great arteries run parallel to each other, without any sign of spiralization $(35,75,76)$. Therefore, we hypothesized that these normal and abnormal anatomical aspects, comparable in humans and in shells, could share a common genetic mechanism $(35,75,77)$.

Recent articles confirmed our suggestion showing the role of Nodal signaling in left-right asymmetry in snails: embryos of dextral (right-handed) species Lottia gigantea express Nodal gene on their right side, while embryos of sinistral (left-handed) species Biomphalaria glabrata express Nodal on their left side $(78,79)$. As in vertebrates the heart designates the situs, in snails the pattern of chirality of the shell (right-handed vs. left-handed) is a sign of situs and of internal organ arrangement (80-82). Moreover, the recent study of Grande and Patel showed that pharmacologic inhibition of the Nodal pathway produces loss of shell chirality, which results in a straight non-spiralized shell (79). Interestingly, it recalls the

\section{REFERENCES}

1. Pexieder T, Blanc O, Pelouch V, Ostàdalovà I, Milerovà $\mathrm{M}$, Ostàdal B. Late fetal development of retinoic acid-induced transposition of great arteries: morphology, physiology, and biochemistry. In: Clark EB, Markwald RR, Takao A, editors. Developmental Mechanism of Heart Disease. Armonk, NY: Futura Publishing (1995). p. 297-307.
2. Ferencz C, Brenner JI, Loffredo C, Kappetein AP, Wilson PD. Transposition of great arteries: etiologic distinctions of outflow tract defects in a casecontrol study of risk factors. In: Clark EB, Markwald RR, Takao A, editors. Developmental Mechanism of Heart Disease. Armonk, NY: Futura Publishing (1995). p. 639-53.

3. Samànek M. Congenital heart malformations:

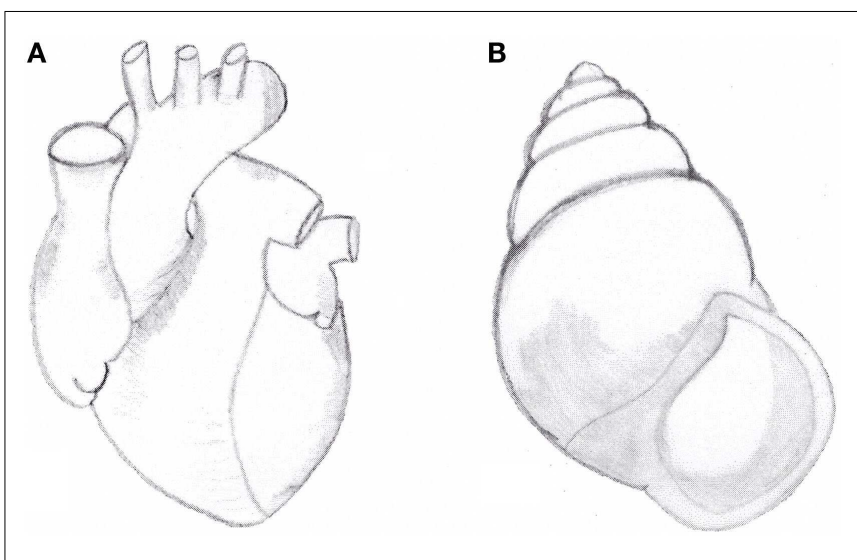

FIGURE 2 | (A) Anatomical aspect of normal heart with situs solitus. Note the right-handed spiral pattern of outflow tract and great arteries. (B) Right-handed shell of the snail Amphidromus perversus rufocinctus.

straight non-spiral phenotype of the great arteries in human TGA in some cases, associated of mutation of the same Nodal gene (67, 80-82). We can conclude that Nodal gene (Figure 1), strongly conserved by phylogenetic mechanisms, is a gene of development involved in the morphogenetic mechanism of normal and abnormal spiralization of great arteries of vertebrates and of normal and abnormal spiralization of the snail shells (78-82).

Moreover, what still needs to be elucidated is the possible relationship between the spiralization of the cardiac outflow tract and of great arteries and the hypothesis of spiralized pattern of myocardial band $(77,83-85)$, the chirally asymmetric paths of intracardiac flow $(86,87)$, and the spiral pattern detected at cellular and molecular level $(83,87)$.

\section{CONCLUSION}

In 1998, Brett Casey, one of the pioneers in the field of genetics of Heterotaxy, asked "Are some complex, isolated heart malformations actually unrecognized manifestations of aberrant left-right asymmetry development? (43)." Nowadays, the overall epidemiological, experimental, and genetic data suggest that TGA, even in situs solitus, can be expression of laterality defects, as it has already been shown for some forms of CAVC (88-91).

Even though the detailed pathogenesis of TGA remains rather mysterious, maybe there are some gleams of light in relation of normal or abnormal spiralization and lateralization mechanisms.

prevalence, severity, survival, and quality of life. Cardiol Young (2000) 10:179-85. doi:10.1017/S1047951100009082

4. Burggren WW. Cardiac design in lower vertebrates: what can phylogeny reveal about ontogeny? Experientia (1988) 44:919-30. doi:10.1007/BF01939885

5. Mair DD, Ritter DG, Ongley PA, Helmholz HF. Hemodynamics and evaluation for surgery of patients with complete transposition of the great arteries and ventricular septal defect. Am J Cardiol (1971) 28:632-40. doi:10.1016/00029149(71)90050-6

6. Rashkind WJ, Miller WW. Creation of an atrial septal defect without thoracotomy: a palliative approach to complete transposition of the great arteries. JAMA (1966) 196:9912. doi:10.1001/jama.1966. 03100240125026 
7. Lang P, Freed MD, Bierman FZ, Norwood WI, Nadas AS. Use of prostaglandin E1 in infants with d-transposition of the great arteries and intact ventricular septum. Am J Cardiol (1979) 44:76-81. doi:10.1016/00029149(79)90253-4

8. Marino B, De Simone G, Pasquini L, Giannico S, Marcelletti C, Ammirati A, et al. Complete transposition of the great arteries: visualization of left and right outflow tract obstruction by oblique subcostal two-dimensional echocardiography. Am J Cardiol (1985) 55:1140-5. doi:10.1016/00029149(85)90651-4

9. Castaneda AR, Norwood WI, Jonas RA, Colan SD, Sanders SP, Lang P. Transposition of the great arteries and intact ventricular septum: anatomical repair in the neonate. Ann Thorac Surg (1984) 38:438-43. doi:10.1016/S00034975(10)64181-1

10. Di Donato RM, Wernovsky G, Walsh EP, Colan SD, Lang P, Wessel DL, et al. Results of the arterial switch operation for transposition of the great arteries with ventricular septal defect. Surgical considerations and midterm follow-up data. Circulation (1989) 80:689-705.

11. Kirklin JW, Blackstone EH, Tchervenkow CI, Castaneda AR. Clinical outcomes after the arterial switch operation for transposition. Patient, support, procedural, and institutional risk factors. Circulation (1992) 86:1501-15.

12. Clark EB. Mechanism in the pathogenesis of congenital cardiac malformations. In: Pierpont ME, Moller JH, editors. Genetics of Cardiovascular Disease. Boston, MA: Martinus Nijhoff Publishing (1986). p. 3-11.

13. Clark EB. Pathogenetic mechanism of congenital cardiovascular malformations revisited. Semin. Perinatol. (1996) 20:465-72. doi:10.1016/S01460005(96)80062-0

14. Ferencz C, Loffredo CA, CorreaVillasenor A, Wilson PD. Genetic and environmental risk factors of major cardiovascular malformations: the Baltimore-Washington Infant Study, 1981-89. In: Ferencz C, Loffredo CA, CorreaVillasenor A, Wilson PD, editors. Perspectives in Pediatric Cardiology. Vol. 5. 1st Edn. Armonk, NY: Futura Publishing Co. Inc. (1997). p. 867-8.
15. Goor DA, Edwards JP. The spectrum of transposition of the great arteries: with special reference to developmental anatomy of the conus. Circulation (1973) 48:40615. doi:10.1161/01.CIR.48.2.406

16. Rokitansky KF. Die Defekte der Scheidewande des Herzens. Vienna: W. Braumuller (1875).

17. Anderson RH, Wilkinson JL, Arnold R, Becker AE, Lubkiewicz K. Morphogenesis of bulboventricular malformations: II. Observations on malformed hearts. Br Heart J (1974) 36:948-70. doi:10.1136/hrt.36.10.948

18. de la Cruz MV, Sánchez Gómez C, Arteaga MM, Argüello C. Experimental study of the development of the truncus and the conus in the chick embryo. J Anat (1977) 123(3):661-86.

19. de la Cruz MV, Arteaga M, Espino-Vela J, Quero-Jiménez M, Anderson RH, Diaz GF. Complete transposition of the great arteries: types and morphogenesis of ventriculoarterial discordance. Am Heart J (1981) 102:271-81. doi:10.1016/S00028703(81)80018-X

20. Van Praagh R, Perez-Trevino C, Lopez-Cuellar M, Baker FW, Zuberbuhler JR, Quero M, et al. Transposition of the great arteries with posterior aorta, anterior pulmonary artery, subpulmonary conus and fibrous continuity between aortic and atrioventricular valves. Am J Cardiol (1971) 28:621-31. doi:10.1016/00029149(71)90049-X

21. Quero-Jiménez M, Perez Martinez V. Uncommon conal pathology in complete dextroposition of the great arteries with ventricular septal defect. Chest (1974) 66:411-6. doi:10.1378/chest.66.4.411

22. Takahashi M, Terasako Y, Yanagawa N, Kai M, Yamagishi T, Nakajima Y. Myocardial progenitors in the pharyngeal regions migrate to distinct conotruncal regions. Dev Dyn (2012) 241(2):284-93. doi:10.1002/dvdy.23714

23. Ward C, Stadt H, Hutson M, Kirby ML. Ablation of the secondary heart field leads to tetralogy of Fallot and pulmonary atresia. Dev Biol (2005) 284:72-83. doi:10.1016/j.ydbio.2005.05.003

24. Bajolle F, Zaffran S, Kelly RG, Hadchouel J, Bonnet D, Brown NA, et al. Rotation of the myocardial wall of the outflow tract is implicated in the normal positioning of the great arteries. Circ Res (2006) 98:421-8.
doi:10.1161/01.RES.0000202800. $85341.6 \mathrm{e}$

25. Marino B. Patterns of congenital heart disease and associated cardiac anomalies in children with Down syndrome. In: Marino B, Pueschel SM, editors. Heart Disease in Persons with Down Syndrome. Baltimore, MD: Paul $\mathrm{H}$ Brookes Publishing (1996). p. 133-40.

26. Jiang ZY, Pircova A, Sekarski N, Hack I, Laurini R, Janzer $\mathrm{R}$, et al. Transposition of the great arteries, pulmonary atresia, and multiple ventricular septal defects associated with multiple cardiac rhabdomyomas in a case of tuberous sclerosis. Pediatr Cardiol (2000) 21:165-9. doi:10.1007/s002469910029

27. Jacobsen P, Hange M, Henningsen K, Hobolth N, Mikkelsen M, Philip J. An (11:21) translocation in four generations with chromosome 11 abnormalities in the offspring. Hum Hered (1973) 23:568-85. doi:10.1159/000152624

28. Digilio MC, Marino B, Giannotti A, Di Donato R, Dallapiccola B. Heterotaxy with left atrial isomerism in a patient with deletion 18p. Am J Med Genet (2000) 94:198-200. doi:10.1002/10968628(20000918)94:3<198::AIDAJMG4>3.0.CO;2-9

29. Van Mierop LHS, Kutsche LM. Cardiovascular anomalies in DiGeorge syndrome and importance of neural crest as a possible pathogenetic factor. Am J Cardiol (1986) 58:133-8. doi:10.1016/00029149(86)90256-0

30. Melchionda S, Digilio MC, Mingarelli R, Novelli G, Scambler P, Marino B, et al. Transposition of the great arteries associated with deletion of chromosome 22q11. Am J Cardiol (1995) 75(1):95-8. doi:10.1016/S00029149(99)80541-4

31. Männer J, Seidl W, Steding G. Complete transposition in a chick embryo demonstrated by scanning electron microscopy. Cardiol Young (1998) 8:396-9. doi:10.1017/ S1047951100006958

32. Marble M, Morava E, Lopez R, Pierce M, Pierce R. Report of a new patient with transposition of the great arteries with deletion of 22q11.2. Am J Med Genet (1998) 78:317-8. doi:10.1002/(SICI)10968628(19980724)78:4<317::AIDAJMG2>3.0.CO;2-I
33. Marino B, Digilio MC, Toscano A, Anaclerio S, Giannotti A Feltri C, et al. Anatomic patterns of conotruncal defects associated with deletion 22q11. Genet Med (2001) 3:45-8. doi:10.1097/00125817200101000-00010

34. Kirby ML, Turnage KL, Hays BM. Characterization of conotruncal malformations following ablation of "cardiac" neural crest. Anat Rec (1985) 213:87-93. doi:10.1002/ar.1092130112

35. Marino B, Capolino R, Digilio MC, Di Donato R. Transposition of the great arteries in asplenia and polysplenia phenotypes. Am $J$ Med Genet (2002b) 110:292-4. doi:10.1002/ajmg.10376

36. Phoon CK, Neill CA. Asplenia syndrome: insight into embryology through the analysis of cardiac and extracardiac anomalies. Am J Cardiol (1994) 73:581-7. doi:10.1016/00029149(94)90338-7

37. Vairo U, Marino B, Parretti di Julio D. Morfologia ventricoloinfundibolare nella eterotassia viscerale con isomerismo sinistro. $G$ Ital Cardiol (1991) 21:969-74.

38. Yasui H, Morishima M, Nakazawa M, Aikawa E. Anomalous looping, atrioventricular cushion dysplasia, and unilateral ventricular hypoplasia in the mouse embryos with right isomerism induced by retinoic acid. Anat Rec (1998) 250:210-19. doi:10.1002/(SICI)10970185(199802)250:2<210::AIDAR11>3.0.CO;2-R

39. Icardo JM, Sanchez de Vega MJ. Spectrum of heart malformations in mice with situs solitus, situs inversus, and associated visceral heterotaxia. Circulation (1991) 84:2547-58. doi:10.1161/01.CIR.84.6.2547

40. Seo JW, Brown NA, Ho SY, Anderson RH. Abnormal laterality and congenital cardiac anomalies: relations of visceral and cardiac morphologies in the iv/iv mouse. Circulation (1992) 86:642-50. doi:10.1161/01.CIR.86.2.642

41. Ferrero GB, Gebbia M, Pilia G, Witte D, Peier A, Hopkin RJ, et al. A submicroscopic deletion in Xq26 associated with familial situs ambiguus. Am J Hum Genet (1997) 61:395-401. doi:10.1086/514857

42. Gebbia M, Ferrero GB, Pilia G, Bassi MT, Aylsworth A, Penman-Splitt M, et al. Xlinked situs abnormalities 
result from mutation in ZIC3. Nat Genet (1997) 17:305-8. doi:10.1038/ng1197-305

43. Casey B. Two rights make a wrong: human left-right malformations. Hum Mol Genet (1998) 7:156571. doi:10.1093/hmg/7.10.1565

44. Nomura M, Li E. Smad2 role in mesoderm formation, left right patterning and craniofacial development. Nature (1998) 393:78690. doi:10.1038/31693

45. Bamford RN, Roessler E, Burdine RD, Saplakoglu U, dela Cruz J, Splitt M, et al. Loss-offunction mutations in the EGF$\mathrm{CFC}$ gene $\mathrm{CFCl}$ are associated with human left-right laterality defects. Nat Genet (2000) 26:3659. doi:10.1038/81695

46. Goldmuntz E, Bamford R, Karkera JD, dela Cruz J, Roessler E, Muenke $\mathrm{M}$. CFC1 mutations in patients with transposition of the great arteries and double-outlet right ventricle. Am J Hum Genet (2002) 70:776-80. doi:10.1086/339079

47. Mohapatra B, Casey B, Li H, Ho-Dawson T, Smith L, Fernbach SD, et al. Identification and functional characterization of NODAL rare variants in heterotaxy and isolated cardiovascular malformations. Hum Mol Genet (2009) 18:861-71. doi:10.1093/hmg/ddn411

48. Okamoto N, Satow Y, Hikada N, Akimoto N, Miyabara S. Morphogenesis of congenital heart anomaly. Bulboventricular malformations. Jpn Circ J (1978) 42:110520. doi:10.1253/jcj.42.1105

49. Stending G, Seidl W. Contribution to the development of the heart. Part II: morphogenesis of congenital heart disease. Thorac Cardiovasc Surg (1981) 29:1-16. doi:10.1055/s-2007-1023435

50. Asami I, Koizumi K. The development of the aortic channel when it arises from the right ventricle: an analytical experimental approach to the morphogenesis of transposition of the great arteries. In: Nora JJ, Takao A, editors. Congenital Heart Disease: Causes and Processes. New York, NY: Futura Publishing (1984). p. 531-44.

51. Bartelings MM, Gittenberger-de Groot AC. Morphogenetic considerations on congenital malformations of the outflow tract. Part 2: complete transposition of the great arteries and double outlet right ventricle. Int J Cardiol (1991) 33:5-26. doi:10.1016/ 0167-5273(91)90147-H
52. Loffredo CA, Silbergeld EK, Ferencz C, Zhang J. Association of transposition of the great arteries in infants with maternal exposures to herbicides and rodenticides. $A m$ J Epidemiol (2001) 153:529-36. doi:10.1093/aje/153.6.529

53. Weber M, Schweitzer M, Mur JM, Andre JM, Tridon P, Vert P. Epilepsy, anticonvulsants and pregnancy. Arch Fr Pediatr (1977) 34:374-83.

54. Redline RW, Abramowsky CR. Transposition of the great vessels in an infant exposed to massive doses of oral contraceptives. Am J Obstet Gynecol (1981) 141:468-9.

55. Abramovici A, Abramovici I, Kalman G, Liban E. Teratogenic effect of chlorimipramine in a young human embryo (abstr). Teratology (1981) 24:42A.

56. Rowland TW, Hubbell JP, Nadas AS. Congenital heart disease in infants of diabetic mothers. J Pediatr (1973) 83:815-23. doi:10.1016/S00223476(73)80374-9

57. Ferencz C, Rubin JD, McCarter RJ, Clark EB. Maternal diabetes and cardiovascular malformations: predominance of double outlet right ventricle and truncus arteriosus. Teratology (1990) 41:319-26. doi:10.1002/tera.1420410309

58. Marino B, Marcelletti C. Complex congenital heart disease after in vitro fertilization. Am $J$ Dis Child (1989) 143:1136-7.

59. Shaw GM, O'Malley CD, Wasserman CR, Tolarova MM, Lammer EJ. Maternal periconceptional use of multivitamins and reduced risk for conotruncal heart defects and limb deficiencies among offspring. Am J Med Genet (1995) 59:536-45. doi:10.1002/ajmg.1320590428

60. Cipollone D, Amati F, Carsetti R, Placidi S, Biancolella M, D'Amati G, et al. A multiple retinoic acid antagonist induces conotruncal anomalies, including transposition of the great arteries, in mice. Cardiovasc Pathol (2006) 15(4):194-202. doi:10.1016/i.carpath.2006.04.004

61. Cipollone D, Carsetti R, Tagliani A, Rosado MM, Borgiani P, Novelli G, et al. Folic acid and methionine in the prevention of teratogen-induced congenital defects in mice. Cardiovasc Pathol (2009) 18(2):100-9. doi:10.1016/j.carpath.2008.02.007

62. Amati F, Diano L, Campagnolo L, Vecchione L, Cipollone D, Bueno
S, et al. Hifl $\alpha$ down-regulation is associated with transposition of great arteries in mice treated with a retinoic acid antagonist. BMC Genomics (2010) 11:497. doi:10.1186/1471-2164-11-497

63. Burn J, Brennan P, Little J, Holloway S, Coffey R, Somerville J, et al. Recurrence risks in offspring of adults with major heart defects: results from first cohort of British collaborative study. Lancet (1998) 351:311-16. doi:10.1016/S01406736(97)06486-6

64. Digilio MC, Marino B, Giannotti A, Dallapiccola B. Familial recurrence of transposition of the great arteries and intact ventricular septum. Am J Med Genet (1997) 73:93-4. doi:10.1002/(SICI) 10968628(19971128)73:1<93::AIDAJMG20>3.3.CO;2-9

65. Digilio MC, Marino B, Banaudi E, Marasini M, Dallapiccola B. Familial recurrence of transposition of the great arteries. Lancet (1998) 351:1661. doi:10.1016/S01406736(05)77720-5

66. Digilio MC, Casey B, Toscano A, Calabrò R, Pacileo G, Marasini $\mathrm{M}$, et al. Complete transposition of the great arteries. Patterns of congenital heart disease in familial precurrence. Circulation (2001) 104:2809-14.

67. De Luca A, Sarkozy A, Consoli F, Ferese R, Guida V, Dentici ML, et al. Familial transposition of great arteries caused by multiple mutations in laterality genes. Heart (2010) 96:673-7. doi:10.1136/hrt.2009.181685

68. Schneider H, Brueckner M. Of mice and men: dissecting the genetic pathway that controls left-right asymmetry in mice and humans. Am J Med Genet (2000) 97:258-70. doi:10.1002/10968628(200024)97:4<258::AIDAJMG1276>3.3.CO;2-\#

69. Moore KL. Apparato digerente. In: Moore KL, editor. Lo Sviluppo Dell'Uomo - Embriologia a Orientamento Clinico. Milano: Casa Editrice Ambrosiana (1993). p. 251-64.

70. Kertesz A, Black SE, Polk M, Howell J. Cerebral asymmetries on magnetic resonance imaging. Cortex (1986) 22:117-27.

71. Kennedy DN, O'Craven KM, Ticho BS, Goldstein AM, Makris N, Henson JW. Structural and functional brain asymmetries in human situs inversus totalis. Neurology (1999) 53:1260-5. doi:10.1212/WNL.53.6.1260
72. Gould SJ, Young ND, Kasson B. The consequences of being different: sinistral coiling in Cerion. Evolution (1985) 39:1364-79. doi:10.2307/2408792

73. Wolfe AJ, Mendelson NH. Twist state phenotypes of Bacillus subtilis macrofibre mutants. Microbios (1988) 53:47-61.

74. Press JR, Sutton DA, Tebbs BM. Convolvulaceae. In: Press JR, Sutton DA, Tebbs BM, editors. Nature Lover's Library Field Guide to Wild Flowers. London: The Reader's Digest Association (1981). p. 250-1.

75. Marino B, Digilio MC, Versacci P, Anaclerio S, Dallapiccola B. Trasposizione delle grandi arterie. Qualche spiraglio nell'inquadramento patogenetico. Ital Heart J Suppl (2002a) 3:154-60.

76. Marino B, Versacci P, Guccione $\mathrm{P}$, Carotti A. Abnormalities of situs. In: Moller JH, Hoffman JIE, editors. Pediatric Cardiovascular Medicine. 2nd Edn. Oxford: Wiley-Blackwell (2012). p. 702-29.

77. Marino B, Corno AF. Spiral pattern: universe, normal heart, and complex congenital defects. $J$ Thorac Cardiovasc Surg (2003) 126(4):1225-6. doi:10.1016 S0022-5223(03)00797-9

78. Hierck BP, Witte B, Poelmann RE, Gittenberger-de Groot AC, Gittenberger E. Chirality in snails is determined by highly conserved asymmetry genes. $J \mathrm{Mol}$ luscan Stud (2005) 71:192-5. doi:10.1093/mollus/eyi023

79. Grande C, Patel NH. Nodal signalling is involved in leftright asymmetry in snails. Nature (2009) 457:1007-11. doi:10.1038/nature07603

80. Oliverio M, Digilio MC, Versacci P, Dallapiccola B, Marino B. Shells and heart: are human laterality and chirality of snails controlled by the same maternal genes? Am J Med Genet A (2010) 152A:2419-25. doi:10.1002/ ajmg.a.33655

81. Versacci P, Digilio MC, Oliverio M, Dallapiccola B, Marino B. The heart and shell. Anatomical and genetic similarities. Am Heart J (2011) 161:647-9. doi:10.1016/j.ahj.2010.12.023

82. Amodeo A, Oliverio M, Versacci P, Marino B. Spiral shapes in heart and shells: when form and function do matter. Eur J Cardiothorac Surg (2012) 41:473-5. doi:10.1093/ejcts/ezr149 
83. Buckberg GD. Basic science review: the helix and the heart. $J$ Thorac Cardiovasc Surg (2002) 124(5):863-83. doi: $10.1067 / \mathrm{mtc} .2002 .122439$

84. Torrent-Guasp F, Ballester M, Buckberg GD, Carreras F, Flotats A, Carrió I, et al. Spatial orientation of the ventricular muscle band: physiologic contribution and surgical implications. J Thorac Cardiovasc Surg (2001) 122:38992. doi:10.1067/mtc.2001.113745

85. Corno AF, Kocica MJ, TorrentGuasp F. The helical ventricular myocardial band of TorrentGuasp: potential implications in congenital heart defects. Eur J Cardiothorac Surg (2006) 29(Suppl 1):S61-8. doi:10.1016/j.ejcts.2006.02.049

86. Kilner PJ, Yang GZ, Wilkes AJ, Mohiaddin RH, Firmin DN, Yacoub MH. Asymmetric redirection of flow through the heart. Nature (2000) 404:759-61. doi:10.1038/35008075

87. Pasipoularides A. Heart's Vortex: Intracardiac Blood Flow Phenomena. Shelton, CT: People's Medical Publishing House (2010).

88. Digilio MC, Dallapiccola B, Marino B. Atrioventricular canal defect as a sign of laterality defect in Ellis-van Creveld and polydactyly syndromes with ciliary and Hedgehog signaling dysfunction. Pediatr Cardiol (2012) 33(5):874-5. doi:10.1007/s00246-012-0270-3

89. Guo Y, Shen J, Yuan L, Li F, Wang J, Sun K. Novel CRELD1 gene mutations in patients with atrioventricular septal defect. World J Pediatr (2010) 6(4):348-52. doi:10.1007/s12519-010-0235-7

90. Zhian S, Belmont J, Maslen CL. Specific association of missense mutations in CRELD1 with cardiac atrioventricular septal defects in heterotaxy syndrome. Am J Med Genet A (2012) 158A(8):2047-9. doi:10.1002/ajmg.a.35457

91. Ghosh P, Bhaumik P, Ghosh S, Ozbek U, Feingold E, Maslen C, Sarkar B, Pramanik V, Biswas P, Bandyopadhyay B, Dey SK. Polymorphic haplotypes of CRELD1 differentially predispose Down syndrome and euploids individuals to atrioventricular septal defect. Am J Med Genet A (2012) 158A(11):2843-8. doi:10.1002/ajmg.a.35626

Conflict of Interest Statement: The authors declare that the research was conducted in the absence of any commercial or financial relationships that could be construed as a potential conflict of interest.
Received: 01 February 2013; accepted: 18 May 2013; published online: 06 June 2013.

Citation: Unolt $M$, Putotto $C$, Silvestri LM, Marino D, Scarabotti $A$, Massaccesi V, Caiaro A, Versacci $P$ and Marino $B$ (2013) Transposition of great arteries: new insights into the pathogenesis. Front. Pediatr. 1:11. doi: 10.3389/fped.2013.00011

This article was submitted to Frontiers in Pediatric Cardiology, a specialty of Frontiers in Pediatrics.

Copyright (C) 2013 Unolt, Putotto, Silvestri, Marino, Scarabotti, Massaccesi, Caiaro, Versacci and Marino. This is an open-access article distributed under the terms of the Creative Commons Attribution License, which permits use, distribution and reproduction in other forums, provided the original authors and source are credited and subject to any copyright notices concerning any third-party graphics etc. 